\title{
EL TERREMOTO DEBIÓ SER EN SANTIAGO
}

\section{Antonio Acevedo Hernández (1939)}

El que hablaba era un hombre recio, blanco, de rostro muy dolorido. Su afirmación representaba el resumen de su esfuerzo de indignación, de su vigor, de su creencia.

Esperé que se calmara un poco y le dije:

-¿Qué decía, usted, señor?

-Que el terremoto debió ser en Santiago.

-Señor, creo un poco exagerada su idea. ¿Se da usted cuenta de la cantidad de gente que aquí habría muerto de la verdadera magnitud de la tragedia?

$-i$ Usted cree que los que murieron en las provincias valen menos que los que habrían desaparecido aquí?

-No señor, pienso que habrían sido mucho más numerosos, que la tragedia habría abarcado proporciones inmensas. Nada más. Para mí, tan respetable es la vida de un hombre de cualquiera parte, como la de uno de aquí.

-Usted no se dio cuenta de la trayectoria del razonamiento que me trajo a esa conclusión que encierra la frase que usted oyó. Decía yo, señor, que si hubiera sido aquí, Santiago, que es la capital, que es Chile, estaría ya reconstruida, o por lo menos tendría las habitaciones de emergencia que hicieran falta.

-Me imagino que en el sur se ha trabajado.

-Sí, señor, se ha trabajado: pero eso no impide lo que ha pasado y lo que pasa. No se ha trabajado lo suficiente. Se vive casi al aire libre, bajo la inclemencia del viento, que brama como toro, que amenaza como fiera y que traspasa la carne, de la lluvia que nos cala y de la alimentación insuficiente. No quiero hablar del vestido ni de la moral del pueblo, víctima de todos los rigores. Han mandado al sur, en demanda de un hipotético trabajo, a una cantidad de infelices que no se han podido colocar, que han carecido de techo y alimento, y que han hecho... lo que han podido.

-Explíquese.

- ¿No lee usted los diarios? ¿No se ha impuesto que los robos y asesinatos están a la orden del día? Yo soy del sur. En mi pueblo, antes del terremoto nadie asaltaba, nadie asesinaba. Ahora roban y matan, porque no tienen qué comer, porque la desesperación se les cuelga del cuello, porque el dolor los muerde como fiera y porque tienen algo que parece rabia y que no es sino ansia de vengarse en cualquier forma de su destino absurdo. 
Se calla un instante, me mira. Sus ojos, antes fulgurantes de indignación, aparecen cubiertos de un velo de lágrimas. Agrega:

-Señor, si pudiera reírme, me reiría de las discusiones del Congreso. ¿Que el dinero se gastó en buena o en mala forma que si las izquierdas, que si las derechas...? Oh!, no, no señor, no es tiempo de derribarse ni de discutir, es el momento de salvar de su desesperación al pueblo de Chile. Desde aquí vio la parte teatral del terremoto, no se ha visto lo que ha pasado después de caído el telón. Ahora hacen tanta falta las visitas de las autoridades como en el primer momento. Antes se lloraba ante lo irremediable, ahora se llora de desesperación, de impotencia, se llora porque no hay valor para morir por el suicidio. Ahora... yo no sé cuándo los hombres que mandan y los que impugnan van a despojarse de su personalismo y van a tomar la alternativa. Hay que hacerlo todo. ¿Comprende? Hay que atenderlo todo, desde Santiago, lleno de teatros, de mujeres bonitas, con distracciones, no se ve la realidad, no se ve la desgracia. Aquí nadie, ni el más infeliz, se alimenta como los obreros de allá, de pan duro y de zanco de harina tostada con agua y sal, ni vive bajo la lluvia ni la furia de los huracanes. Eso es lo que debieron saber las autoridades, sobre esa base debería orientar su labor. Nosotros creemos en sus buenas intenciones, hemos visto que han tratado de remediar nuestros males, pero en una proporción que nos ha hecho mucho daño. Mi protesta no es agresiva, es afligida, es desesperada: ¡hablo en nombre de la patria, de la familia, de la vida!

Aquel hombre no habló más, pero su silencio fue para mí más impresionante. Yo, como él, me desentiendo de discusiones, de zancadillas y de bizarrías, y en nombre de la patria, de la familia y de la vida, he tratado de repetir sus palabras.

Acevedo Hernández, Antonio. El terremoto debió ser en Santiago. Las Últimas Noticias. Santiago de Chile, 13 agosto, 1939. 